\title{
Commonalities between the Shroud of Turin and the Sudarium of Oviedo
}

\author{
Alfonso Sánchez Hermosilla \\ Medical Examiner, EDICES Director (Spanish Sindonology Researh Centre Team), Spain
}

\begin{abstract}
In 1989 EDICES (Spanish Sindonology Research Centre Team) started researching about the Sudarium of Oviedo, developing the pioneer research started in the sixties by Monsignor Giulio Ricci, who was a member of the Papal Curia and President of the "Roman Centre of Sindonology"a, and furthermore, he was a scholar of the Gospel of Saint John, the reading of chapter 20, Bible verses 4-8: “4 They were running together, but the other disciple ran faster than Peter and was the first to arrive at the tomb. ${ }^{5}$ Bending down to take a look, he saw the linen cloths lying there, but he didn't go in. ${ }^{6}$ Following him, Simon Peter entered the tomb and saw the linen cloths lying there. ${ }^{7}$ He also saw the face cloth that had been on Jesus' head. It wasn't with the other clothes but was folded up in its own place. ${ }^{8}$ Then the other disciple, the one who arrived at the tomb first, also went inside. He saw and believed." This made him look for a second funerary linen used to wrap the corpse of Jesus of Nazareth. This seek led him to the Sudarium of Oviedo. The similarity of the shape of the stains and its size with the Shroud of Turin made him think that he had really found the relic which Saint Joan mentions. From the Forensic Anthropology and Forensic Medicine point of view, all the information discovered by the scientific research is compatible with the hypothesis that the Shroud of Turin and the Sudarium of Oviedo covered the corpse of the same person.
\end{abstract}

\section{The Sudarium of Oviedo}

The Sudarium of Oviedo is a relic which is kept in the Cathedral El Salvador in Oviedo (Spain), in particular in the Cámara Santa, a chamber located in an attached building, built expressly to keep this relic together with other relics by king Alphonso II el Casto (the pure), and was also used as the chapel of its palace. This linen is located in this region of the north of Spain from 812 or 842 according to historians, and it is called Sudarium Domini or El Santo Sudario de N.S.J.C.

The relic is made of linen and measures approximately $84 \times 54$ centimetres, according to what Franca Pastore Trosello expressed at the Congress of Siracusa ${ }^{\mathrm{b}}$. The textile structure of the Sudarium of Oviedo and the one of the Shroud of Turin have the same composition, specifically linen; the same fibre thickness and both have been spinned by hand with sprain in "Z". However, they have been knitted in a different way: serge on spike for the Shroud of Turin and octagonal weave (taffeta) for the Sudarium

\footnotetext{
a Ricci, G. L'Uomo Della Sindone é Gesú, 2a Edición, 1969.

b AA.VV., La Sindone, indagini scientifiche, Atti del IV Congresso Nazionale di Studi sulla Sindone, Siracusa, 1987, Ed. Paoline, Cinisello Balsamo (MI), 1988.
}

This is an Open Access article distributed under the terms of the Creative Commons Attribution License 4.0, which permits unrestricted use, distribution, and reproduction in any medium, provided the original work is properly cited. 
of Oviedo. Nevertheless, the last one does not have any type of image similar to the one that can be appreciated in the Shroud of Turin, but there are a lot of blood stains and other body fluids from a human corpse, as was determined in 1985 by Dr. Pierluigi Baima Bollone, confirming that the blood was $\mathrm{AB}$, data which was supported by Dr. José Delfín Villalaín Blanco. ${ }^{\mathrm{c}}$

The morphological study of stains in both linens reveal an obvious similarity between them, due to the corpse which created them was manipulated very carefully in both cases. Furthermore, the Sudarium of Oviedo was fastened to the head and meticulously tightened to it, guaranteeing its position with a lot of precise sewing done by a needle and cotton thread. One must take into account that the morphological similarity between the blood stains do not need to be the same: different heads may produce very similar stains and the same head may produce very different stains. However, both group of stains match very well, not only in their relative position but also in their superficial size ${ }^{\mathrm{d}}$. Moreover, if we compare both relics, we should add the correspondence on the distances between the staining injuries which originated the stains.

The linen from Oviedo has proved to be really protective with the information which contains, and only reveals it to people who spend a lot of time and effort. Nevertheless, it has permitted to state, according to the current scientific knowledge, that it could have had a funerary usage in the first century of our time, in which was known as the Roman Province of Judea.

\section{Commonalities from the forensic medicine}

We have to take into consideration that the current stains on the Shroud of Turin and the Sudarium of Oviedo have remained because the blood and other body fluids which originated them were not completely dry. Otherwise its lack of adhesiveness would have prevented them from fixing into the cloth cellulose and would not have remained until now. It was therefore necessary that the blood was fresh, or, if it was already dry, it should have been rehydrated somehow, before covering the corpse with the Linen. This means that it is very probable that the corpse presented other lessons that we do not know nowadays, because they did not bleed or because the blood scabs were dry and were not rehydrated by another body fluid, or by other means.

We also have to consider that the Sudarium of Oviedo covered the face of the corpse before the Shroud of Turin, what have two consequences:

1. The Sudarium of Oviedo had a screen effect, which preserved humidity of the corpse fluid stains, allowing that when this was moved away and the corpse was covered with the Shroud of Turin, the stains could coat it. This would be a positive influence on the second Shroud. Due to this reason, in the reverse of the Shroud of Turin there are fluid stains that have gone through the thick of the cloth. If it had not been like this, they may not have gone through the cloth completely, and would have just coated the surface in contact with the corpse.

2. In contrast, part of the information that the Sudarium of Oviedo contains, was not transferred to the Shroud of Turin. It is just present in the first one, as it happens with the centre of the blood drop from the trail in epsilon at the forehead.

From the Forensic Medicine point of view, there are a high number of matches between the injuries which can be appreciated in the image of the Shroud of Turin, and those which can be appreciated in the criminologist research of the Sudarium of Oviedo. The most important are stated below.

The blood stains attributed to the thorns of the crown can be appreciated in both relics with a high similarity in the distance which separates them.

\footnotetext{
c VILlALAÍN BLANCO, JD. Estudio Hematológico Forense realizado sobre el Santo Sudario de Oviedo. Sudario del Señor. Actas del I Congreso Internacional sobre el Sudario de Oviedo. Oviedo, 1994, Página 153.

d AA.VV. Actas del II Congreso Internacional sobre el Sudario de Oviedo.
} 
In the Sudarium of Oviedo there is a blood stain that belonging from the nose and mouth, goes up in an anti-gravitational direction, and is extended to the forehead area. However, in its itinerary, the fluid staining found a series of obstacles, compatible with the anatomic and traumatic injuries present at the face of the Shroud, such as the blood clot in epsilon, as well as the left swollen, inflamed forehead region, and other clots at the top area of the left eyebrow and the prominent frown arcs.

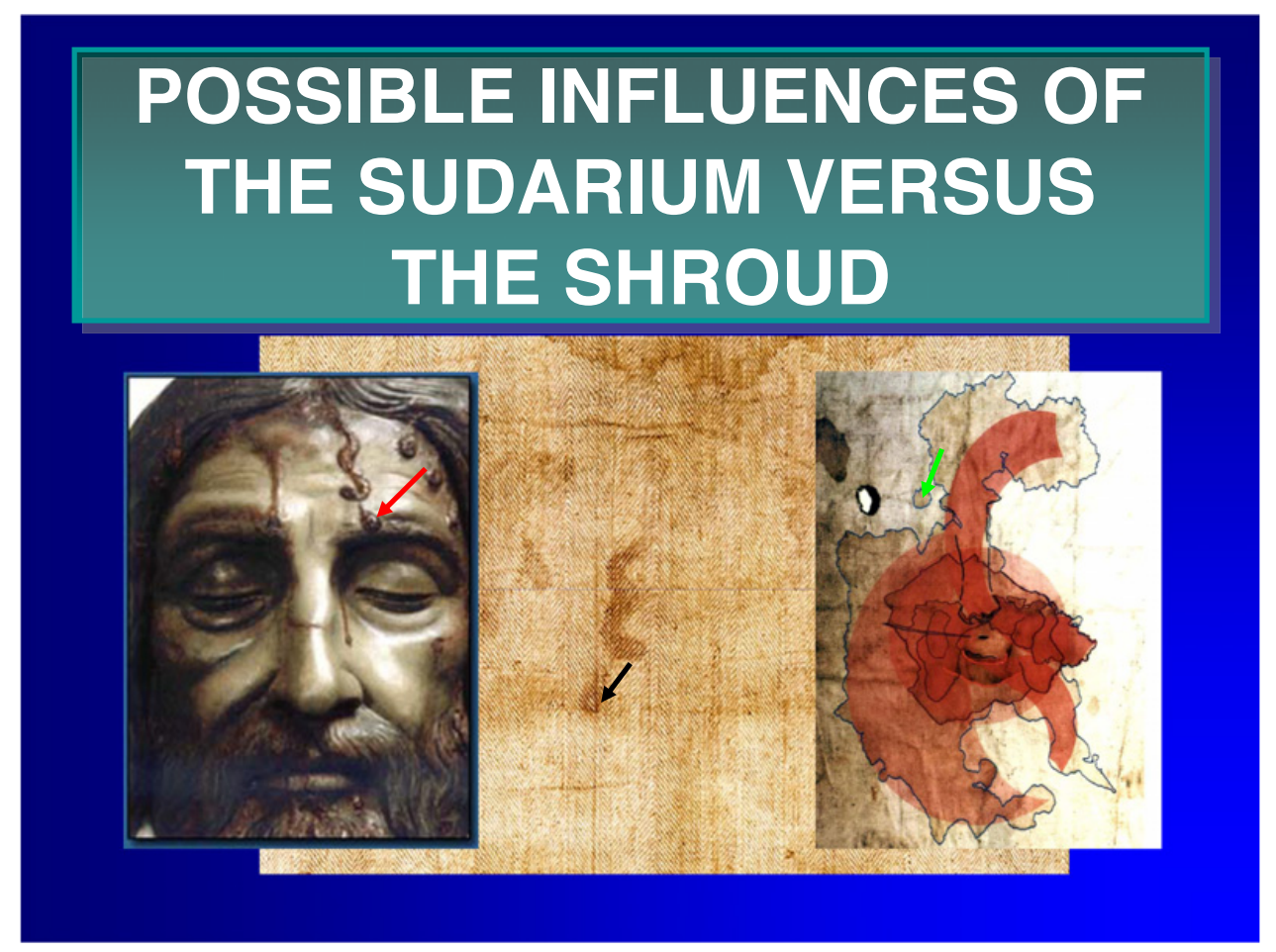

Both cheeks are swelled up, especially the right one, which shows a swelling of 1.5 centimetres over its usual size minimum, what has really influenced the behaviour of the fluids which moved through the face, staining the linen, since every time they found an obstacle, they had to avoid it through the area which offered less resistance in its way.

The right external area of the nose is inflamed as well, and the end of the nasal appendix is moved to the left, with the circumstance that the handling that the corpse suffered caused the opening of the left nostril, while the right nostril is blocked. The surface of the nose in both linens is very similar; in the Sudrium of Oviedo it has an area of $2.280 \mathrm{~mm}^{2}$, and in the Shroud of Turin $2.000 \mathrm{~mm}^{2}$. Moreover, by the middle of the right area of the nose there is a zone which is inflamed which measures $100 \mathrm{~mm}^{2}$ in the Sudarium of Oviedo and $90 \mathrm{~mm}^{2}$ in the Shroud of Turin.

It is convenient to bear in mind that in the relics there are obvious signs of corpse rigidity, especially in the neck, as well as deformation by pressure on several parts of the face. Moreover, the mouth is half-open, and from it a shedding of blood flows, as was discovered by Ricci at the time.

The chin presents a prominent aspect, probably as a direct consequence of the inflammation of the area, and it seems that it has lost part of the capillary stems that formed the beard and the moustache; something that together with the inflammation of the chin, conditioned the way in which blood moved through these areas of the face, what caused similar stains in the area in both relics.

One of the stains of the Sudarium of Oviedo seems to be compatible with some of the wounds caused by Flagrum Taxilatum in the right area of the neck, and it seems to be compatible with some of the marks of the Shroud of Turin attributed to this reason. 
At the occipital area there are a lot of stains of vital blood, that is to say, that was dropped when the condemned was still alive. They are very similar in both linens, and seem to be connected to sharp wounds in the scalp. Furthermore, they match to the ones that a crown of thorns would produce.

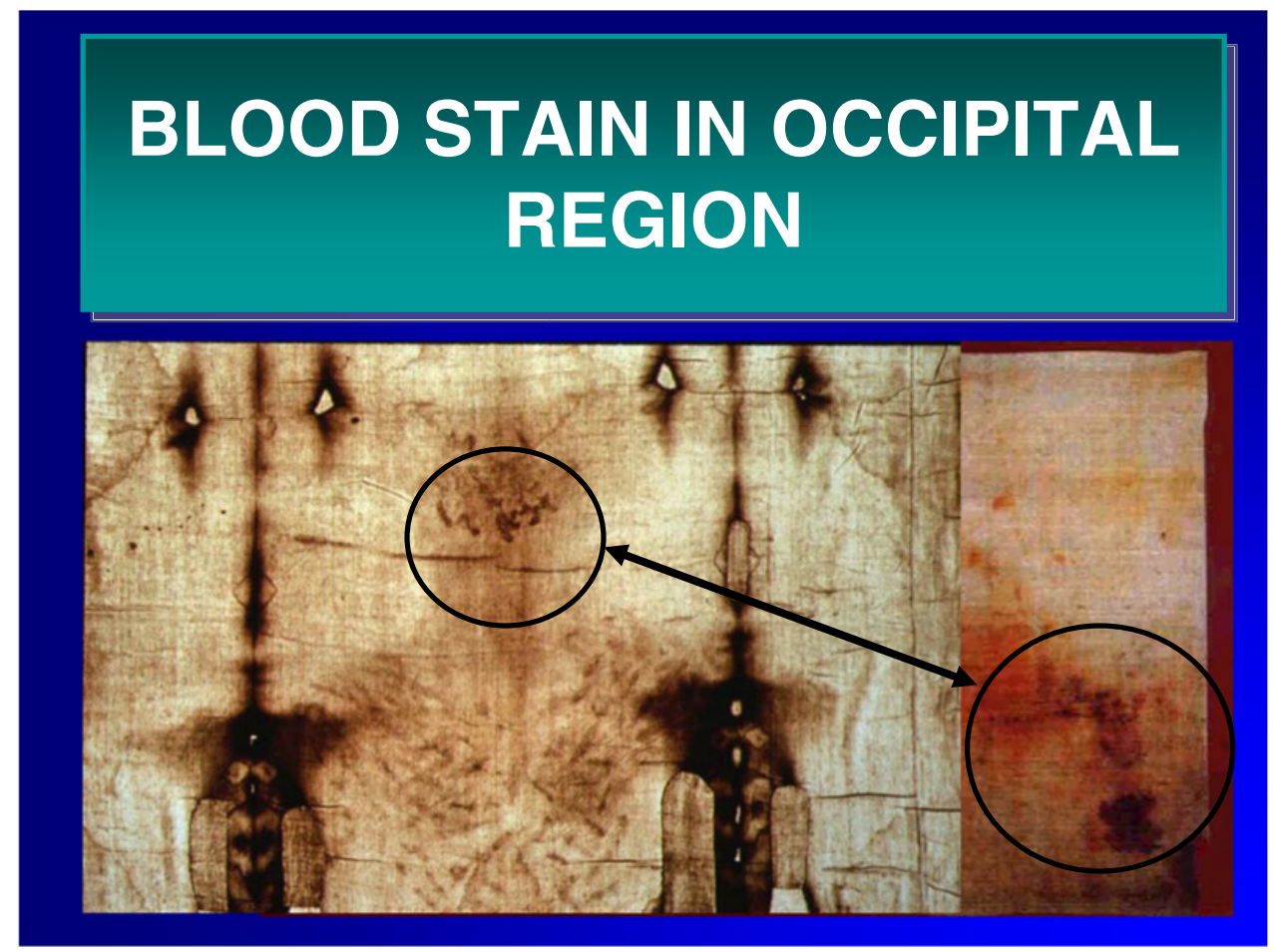

In the area of the $7^{\text {th }}$ cervical vertebra or vertebra prominens in the Sudarium of Oviedo there is a stain with the shape of a butterfly, which could have been produced as a consequence of sewing carefully the linen from Oviedo to the hair of the corpse covered with fresh blood. This way of sewing the linen to the hair made that this one adopted the shape that can be appreciated in the image of the shroud. Some authors believed it could be a kind of ponytail or braid, setting up another proof of the influence that the previous use of the Sudarium of Oviedo may have had over the Shroud of Turin. On both sides of the stain there are other ones, produced by corpse fluids, which are similar in the Sudarium and the Shrouds.

The Sudarium of Oviedo covered the head, face and neck of the corpse. Though at the rear it covered the top area of the back, at the front part it was carefully tightened to both collar bones. In the area of the relic which covered the right top area of the back there is a stain, located at the left bottom corner of the reverse of the linen, known as stain of the corner or stain of Ricci, since this is an area where Monsieur Giulio Ricci took a piece to investigate with it, and could have been produced as a consequence of the orifice exit of the wound produced by the lance. Said stain has its equivalence in the Shroud of Turin and could have been unnoticed until now due to its morphological similarity to the stains attributed to the flagellation.

Apart from this stain, there are some other indirect signs of the lance, such as plentiful clots of fibrin which appear in the called diffused stain and stain in accordion. The only plausible hypothesis that justifies its presence in these areas of the linen from Oviedo is that said clots were produced in the thorax, probably during the flagellation, and could only get the linen from Oviedo as a consequence of 
a penetrating wound into the thorax, compatible with the lance, that communicated the thorax cavities with the aerial tracts and with the exterior. ${ }^{\mathrm{e}}$

There are no objective signs of corpse putrefaction in none of the linen, though in both of them there are signs of corpse rigidity.

\section{Correspondences from the forensic anthropology}

Mr. Ángel del Campo Francés initiated the anthropological research of the corpse that originated the stains of the Sudarium of Oviedo ${ }^{\mathrm{f}}$, research which was followed by Mr. Guillermo Heras Moreno and Mrs. Margarita Ordeig Corsini. ${ }^{g}$

The discovery of the mark of the right ear of the head of the corpse in the Sudarium of Oviedo allowed to determine the location of the even numbers measurement cranium points, while the odd had already been identified at the medium line, not only in the face, Glabela, Nasion, Rhinion, Subnasal y Mentoniano, but also at the back area of the cranium Inion ${ }^{\mathrm{h}}$. In the Shroud of Turin it is not possible to determine the even numbers measurement cranial points, since in the image of the shroud the side areas of the body do not appear, but the odd measurement cranial points can be easily found.

This way it has been determined that the perimeter of the head must have been about 62 centimetres, considering that the inflammation of the soft tissues as a consequence of the physical maltreatment that he suffered could have contributed considerable to increase this size. The atrial drinks, that is, the ears, are located at 17 centimetres from the face axis, the height of the face is estimated in 18.5 centimetres, its width in about 14 centimetres, the biggest width of the nose in about 2.3 centimetres, its length between 6-7 centimetres, its projection around 3 centimetres and the distance between the Rhinion measurement cranial point and the Mentoniano would be 13 centimetres.

Once the cranial proportions in both relics are known, and after its comparison, it is checked that they concur, what has permitted the sculptor D. Juan Manuel Miñarro López to make a reconstruction of the face of the Man on the Shroud of Turin; said reconstruction is absolutely compatible with the face of the Man of the Sudarium of Oviedo, not only in his anthropometric proportions, but also in the traumatic wounds that both present.

In fact, the compatibility of the face once it was sculpture was verified, since the anatomic areas that are stained with blood in the Sudarium of Oviedo were covered with ink, and then a piece of linen was put on it and carefully adjusted. When the result was checked, the impressions were very similar to the ones that appeared in the linen from Oviedo.

\section{Conclusions}

The new discoveries done after the inspection of the Sudarium of Oviedo, both macroscopic and microscopic, coincide with the accumulated knowledge that already existed. Said research was initiated by Mons. Ricci, and followed by EDICES. Additionally, the information which contains matches what the researchers who have had access to the Shroud of Turin have published, and with the information provided by the Gospels about the facts related to the Passion, Death and post-mortem handling of the corpse of Jesus of Nazareth.

\footnotetext{
e SÁNCHEZ HERMOSILLA, A. El Sudario de Oviedo y la Síndone de Turín. Actas del I Congreso Internacional sobre la Sábana Santa en España. Valencia 28-30 de abril de 2012.

${ }^{\mathrm{f}}$ CAMPO FRANCES, A. El Sudario de Oviedo, análisis matemático de las manchas. Actas del I Congreso Internacional sobre el Sudario de Oviedo. Servicio de publicaciones de la Universidad de Oviedo, 1994.

g HERAS MORENO, G., ORDEIG CORSINI, M., "Consideraciones geométricas sobre la formación central de las manchas del Sudario de Oviedo" Actas II Congreso Internacional sobre el Sudario de Oviedo. Abril, 2008.

h MIÑARRO LÓPEZ J.M. Reconstrucción Anatómica Tridimensional Basada en el Sudario de Oviedo y la Síndone de Turín, Oviedo Relicario de la Cristiandad, Actas del II Congreso Internacional sobre el Sudario de Oviedo, Oviedo, 2007, pp. 691-714.
} 
These discoveries are compatible with an intense physical maltreatment, with multiple traumas that produce bruised wounds, bleeding wounds, sharp wounds and bruised wounds, what probably includes flagellation at the roman manner using a Flagrum Taxilatum.

Although in the Sudarium of Oviedo there are no objective final signs of the presence of a penetrating injury into the thorax, there are plenty of indirect signs that point to this possibility. When writing this report, we do not have another alternative hypothesis to the previously expressed, with real possibilities of being truth. This damage must have been produced after the death of the Man of the Shroud, and not when he was still alive.

All the information provided by the study and research of these relics matches to what, from the Forensic Medicine point of view, was to be expected to happen in linens of these characteristics if they had covered the head of a corpse that had received all the injuries that suffered Jesus of Nazareth according to the Gospels.

We are aware of the lack of up-to-date and agreed protocols by the scientific community for the investigation of archaeological pieces similar to the Sudarium of Oviedo and the Shroud of Turin. This is a field where researchers are still pioneer, what makes very difficult the progress in the investigation, due to the necessity to be cautious and efficient. ${ }^{i}$

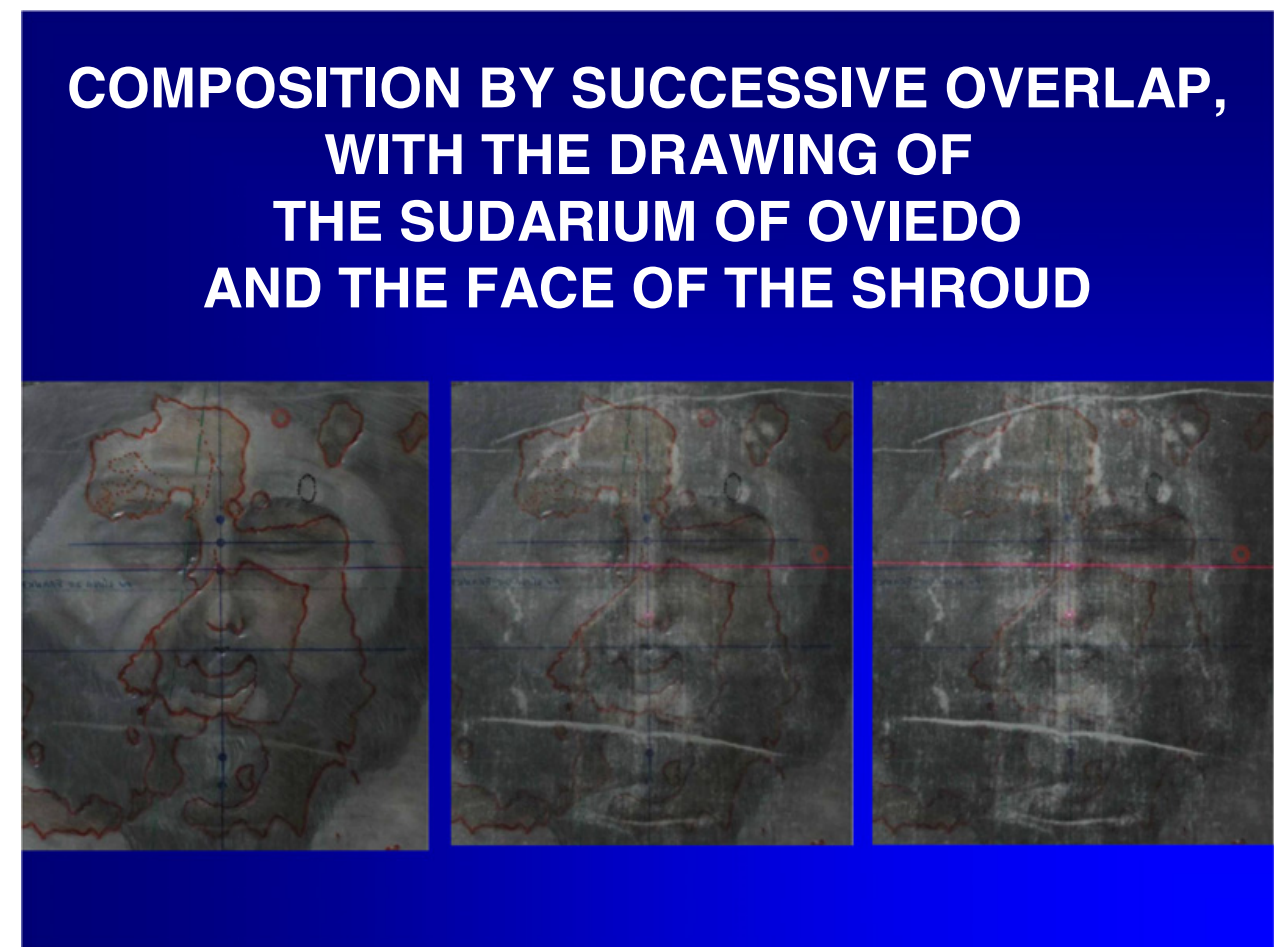

The discoveries that have been found open new areas of research that were unexpected until now. A priori they seem to be really promising, what includes new stains that were unknown until now.

For this reason, it seems reasonable to believe that it would be convenient to carry out new direct research in the future on both Relics and to relate the discoveries that have been verified in the Sudarium of Oviedo to possible matches to the Shroud of Turin.

\footnotetext{
i Barberis, B., Perspectivas de futuro en la investigación sobre la Síndone. Actas del I Congreso Internacional sobre la Sábana Santa en España. Valencia 28-30 de abril de 2012.
} 


\section{References}

[1] AA.VV., La Sindone, indagini scientifiche, Atti del IV Congresso Nazionale di Studi sulla Sindone, Siracusa, 1987, Ed. Paoline, Cinisello Balsamo (MI), 1988

[2] Barberis, B., Perspectivas de futuro en la investigación sobre la Síndone. Actas del I Congreso Internacional sobre la Sábana Santa en España. Valencia 28-30 de abril de 2012

[3] Campo Frances, A. El Sudario de Oviedo, análisis matemático de las manchas. Actas del I Congreso Internacional sobre el Sudario de Oviedo. Servicio de publicaciones de la Universidad de Oviedo. 1994

[4] Heras Moreno, G., Ordeig Corsini, M., “Consideraciones geométricas sobre la formación central de las manchas del Sudario de Oviedo" Actas II Congreso Internacional sobre el Sudario de Oviedo. Abril, 2008

[5] Heras Moreno, G., Villalaín Blanco, J.D., Rodriguez Almenar, J.M. Estudio Comparativo entre el Sudario de Oviedo y la Síndone de Turín, III Congresso Internazionale di Studi Sulla Sindone, Torino, 5/7 de Junio de 1998

[6] Heras Moreno, G., Villalaín Blanco, J.D. El Sudario de Oviedo ¿Envolvió la cara de Jesús?, El Sudario de Oviedo, Hallazgos Recientes, Centro Español de Sindonología, Valencia, 1998, pp. 371/155-373/157

[7] Heras Moreno G., Villalaín Blanco J.D. El Sudario de Oviedo ¿Envolvió la cara de Jesús?, El Sudario de Oviedo, Hallazgos Recientes, Centro Español de Sindonología, Valencia, 1998, pp. 367/151-160/376

[8] Heras Moreno G., Jackson J., Villalaín Blanco J.D., Baima Bollone P., Conclusiones Finales. Sudario del Señor. Actas del I Congreso Internacional sobre el Sudario de Oviedo, Oviedo, 1994. pp. 467-474

[9] Miñarro López J.M., Reconstrucción Anatómica Tridimensional Basada en el Sudario de Oviedo y la Síndone de Turín, Oviedo Relicario de la Cristiandad, Actas del II Congreso Internacional sobre el Sudario de Oviedo, Oviedo, 2007, pp. 691-714

[10] Ricci G., Comparación Morfológica entre las huellas microscópicas del Sudario y las Anatómicas de la Faz Sindónica, Actas del I Congreso Internacional sobre el Sudario de Oviedo, Oviedo, 29, 30 y 31 de octubre de 1994, p. 148, p. 367

[11] Ricci, G., L’Uomo Della Sindone é Gesú, $2^{\text {a }}$ Edición, 1969

[12] Sagrada Biblia, Versión Oficial de la Conferencia Episcopal Española. Biblioteca de Autores Católicos. Madrid, 2010

[13] Sánchez Hermosilla, A. El Sudario de Oviedo y la Síndone de Turín. Actas del I Congreso Internacional sobre la Sábana Santa en España. Valencia 28-30 de abril de 2012

[14] Sánchez Hermosilla, A. Las lesiones punzantes en el cuero cabelludo. Actas del I Congreso Internacional sobre la Sábana Santa en España. Valencia 28-30 de abril de 2012

[15] Villalaín Blanco J.D., Estudio Hematológico Forense realizado sobre el Santo Sudario de Oviedo, Sudario del Señor, Actas del I Congreso Internacional Sobre el Sudario de Oviedo, Oviedo, 29, 30 y 31 de octubre de 1994, p. 142

[16] Villalaín Blanco J.D., Heras Moreno G., El Sudario de Oviedo, estudio hematológico, forense y geométrico. El Sudario de Oviedo. Hallazgos recientes, Centro Español de Sindonología, Valencia, 1998, pp. 57/273-99/315

[17] Villanueva Cañadas E., Indicios en Medicina Legal: manchas, pelos y otros indicios, Medicina Legal y Toxicología. Editorial Masson, 6a Edición, Barcelona, 2004, pp. 1255-1270 